International Journal of Instruction e-ISSN: 1308-1470 • www.e-iji.net
October $2017 \bullet$ Vol.10, No.4

p-ISSN: 1694-609X

pp. 307-324

Received: $16 / 02 / 2017$

Revision: 25/07/2017

Accepted: 30/07/2017

\title{
Rethinking Students' Dispositions towards Civic Duties in Urban Learning Ecologies
}

\section{Olugbenga Adedayo Ige}

Dr., Postdoctoral Research Fellow, School of Education Studies, University of the Free

State, QwaQwa Campus, South Africa, olugbengaige@gmail.com

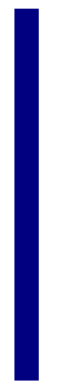

This study explored the causative influence of thinking dispositions on secondary school students' civic attitudes in school ecologies. 167 students from eight selected secondary schools in northern and southern Nigeria responded to the Senior Students' Thinking Dispositions Questionnaire (SSTDQ), and Students' Attitude to Civic Education Scale (SACES). Results of the stepwise linear regression model declared that absolutism, superstition, and dogmatism were the potent predictors that are strongly connected to students' civic attitudes. The study has inferences for teachers' development viz a viz teaching students' civic attitudes from inside out (critical teaching that uses social tools as yardstick) in school ecologies.

Keywords: critical discourse, civic attitudes, urban learning ecologies, absolutism, superstitious thinking, dogmatism

\section{INTRODUCTION}

Civic education develops in students the ability to make informed judgements (Hess, 2004; Westheimer \& Kahne, 2004; Yuen, 2016). An interesting view was expressed that 'when nations transit from one form of government to another, civic education plays a veritable role in the preparation of citizens for a modern political reality (Tobin, 2010). Tobin's (2010) opinion attests to the nation building worth of civic education. Also, in discussing the global importance attached to civic education, Campbell (2007) stated that public schools in America have an express fiat to deliver civic education lessons to their students. This is corroborative to claim of Cameron (2010) that civic education is the master key that can open the 'Big Society'. To him, civic education is conceived as a key to a flawless society where citizens take active roles in their societal development and also collaborate to unravel community 'Gordian knots'.

The cyber age evolution that began in the early $19^{\text {th }}$ century came with the realities that teaching must be geared to helping students disposed to thinking in a critical manner not without infusing its own registers and way of critical thinking to the universe. Kokdemir (2003) observed that the advancement that critical thinking dispositions have brought to

Citation: Ige, O. A. (2017). Rethinking Students' Dispositions towards Civic Duties in Urban Learning Ecologies. International Journal of Instruction, 10(4), 307-324. https://doi.org/10.12973/iji.2017.10418a 
students' learning outcomes is not restricted to courses in selected fields, but to all disciplines. The pacy academic life of the cyber age has led teachers to examine the usefulness of the critical thinking dispositions. These include the likes of Klooster (2001) who affirmed that critical thinking dispositions comprises independent thinking which has information as the activating point, and not the terminal point. These points start with questions and problems needing solution, seeks logical arguments, and above all a social thinking platform. Also the likes of (Fero, O'Donnell, Zullo, Dabbs, Kitutu, Samosky, et al., 2010) in a recent research that deduced that critical thinking possesses diverse prime components such as individual's ability to search and decipher information, cum interconnection with knowledge, reasoning, identification, skills of cognition, and scrutiny of alternative frames of reference.

Also, Ennis (1987) asserted that critical thinking is a reasonably reflective thought process that is pre-occupied with the determination of what to do or believe. Consequent on the salient responsibilities of schools in the twenty-first century to mould the lifeprospects of students (Villegas, 2007), teachers cannot disregard critical thinking constructs that are of direct relevance to teaching and practice that would aid their students to take important civic decisions. With the shift from Soviet pedagogy to thinking powered educational system to meet the dynamics of changing workplace in Kazakhstan (Burkhalte \& Shegebayev, 2010), no educational system across the world might be able to close her educational frontiers to the critical thinking revolution.

Ogundokun and Adeyemo (2010) observed that educational researchers have started addressing the soft side of individual differences which included mood, emotions, and feelings in relation to student learning outcomes. Fairbrother (2003) contributed valuable information on critical thinking disposition and students' national attitudes. This scholar discovered integral interactions between critical thinking and aspects of socialization process of students as well as their abilities to form individual opinions about national affairs in Hong Kong and Mainland China. The prescient of Ennis (1987) came to fore in the research instruments constructed by Fairbrother (2003) on critical thinking dispositions which was painstakingly tailored to the political socialization process in Hong Kong and China., Oguz and Saricam (2016) delved into the relationship between critical thinking disposition and locus of control in pre-service teachers, and established that gender differences exist in the critical thinking dispositions of pre-service teachers.

Beyond the learning outcomes of students, critical thinking constructs have been found appropriate for natural hazards; the logical framework of this study that by and large, the cyber age has come to stay and it has multi-effects on the educational outcome of students in the urban societies and beyond. In a recent study, Nakagawa (2016) discovered through cyber aid household that earthquake preparedness was necessary, while inquisitiveness also moderated the association between earthquake preparedness of households and risk perception.

Despite considerable efforts by educational researchers to investigate the influence of critical thinking dispositions on students' learning outcomes, there are few research focusing on the effect of critical thinking dispositions on students' civic attitudes 
(Fairbrother, 2003; Rickles, Schneider, Slusser, Williams, \& Zipp, 2013). Ergo, this study will extend the body of knowledge in civic education by examining the moderating influence of critical thinking disposition factors on students' civic attitudes in school learning ecologies. The current study is integral for the following reasons: primarily, it aims to ascertain which of the critical thinking disposition sub -constructs will be the most potent predictors of students' civic attitudes. Second, to determine which of these potent predictors would be the most potent predictor of students' civic attitudes. Consequent on this background, the study aims to answer the following research questions:

1. Which of the critical thinking disposition sub-constructs will be the potent predictors of students' civic attitudes?

2. What are the combined contributions of the potent critical thinking disposition sub-constructs to the criterion of students' civic attitudes?

3. What are the relative contributions of the potent critical thinking disposition sub-constructs to the criterion of students' civic attitudes?

\section{Literature Review}

\section{Critical Thinking Dispositions}

Critical thinking is considered necessary for youngsters who are interested in furthering their education; who strive to win vacant jobs, in order to become responsible citizens (Mok \& Yuen, 2016). Critical thinking connotes different things to several educational researchers and this accounted for the divergent opinions on its definitions. It should however be noted that critical thinking skills differ from critical thinking dispositions. The former means ability to think critically, while the latter connotes willingness to do so (Huber \& Kuncel, 2016) Franco, Costa, Butler, and Almeida (2017) remarked that critical thinking is a variant of good thinking that encompasses dispositions and cognitive skills that brightens a student's chances of success in academic settings, job market and daily life. It was added that dearth of critical thinking could result to defeatist life events such as rashness, academic negligence, poor impulse control, slackness, mismanagement, and health neglect. Mok and Yuen (2016) maintained that critical thinking is differentiated by two primary elements namely; character, attitudes, or dispositions and it abilities or skills. However, it should be noted that effective thinking requires both dispositions and abilities.

Facione (1990) reported a robust conception of critical thinking emanated from the cross-pollination of ideas among forty-six educational researchers using the Delphi method of qualitative enquiry. Consensus was reached that critical thinking is a purposeful self-regulatory judgment which results in interpretation, analysis, evaluation, and inference, as well as explanation of the evidential, conceptual, methodological, criteriological, or contextual considerations upon which that judgment is based. These scholars shed light on what constitutes critical thinking, what it is, and why it counts. The forty-six experts utilized the allegorical expression to affirm that critical thinking dispositions must have a 'critical spirit' which means 'a probing inquisitiveness, a keenness of mind, a zealous dedication to reason, and a thirst for valid information' (Facione, 2013). At present, there are increasing conceptions of critical thinking 
dispositions, however in this study, critical thinking dispositions connoted flexible thinking, openness value, dogmatism, categorical thinking, beliefs identification, counterfactual thinking, superstitious thinking and absolutism.

Stanovich and West (1997) developed the flexible thinking constructs from variety of critical thinking literature such as Barren (1993), which emphasized actively openminded thinking which encompasses reflectiveness rather than impulsivity such as soliciting and processing information that conflicts with an individual to alter his/her beliefs on the presentation of an antithetical evidence. In this study, flexible thinking connotes the students' cultivation of reflective as against rash dispositions. Rex (2012) affirmed that openness is a vital component of critical thinking which is manifested in the fervency to listen to variety of opinions and facts about a problem. Hare (2004) further added that one fundamental of education that emphasized the Rusellian conception of openness is the virtue that checks habit and desire from making students tolerate fanaticism which emanates from convictions that their opinions are absolutely certain. In this study, openness value means students ability to review societal ideals that challenges their open-mindedness.

Doyle (2014) defined 'dogmatism' as students' conjectural positiveness in-events of opinion i.e. haughty assertion of standpoints as truths. MacDonald (1992) extended 'dogmatism' to the circles of instructional strategies, and described it as a situational construct which connotes students or teachers preference for an instructional strategy. From literature, it could be seen that educational researchers have a bipolar view of the term 'dogmatism'. Brock, Paddock, and Thomsom (1993) utilized the Rokeachian lenses and pointed out that dogmatism is the extent to which a students' belief system is bolted or open. It was further affirmed that dogmatic behavior is usually termed 'close minded', while a less dogmatic student is known as 'open minded'. In this study, students that scored low on the dogmatic scale are 'open-minded' while students with higher scores are 'close minded'. However, Doyle (2014) cautioned teachers that when students hold dogmatic beliefs, they basically close their minds to alternative frames of references.

Studies have shown that students usually bring with them the perspectives of supernatural forces peculiar to the traditional societies in which they are brought up (Block, 1994; Undie, Duruamaku, Agba \& Undie, 2015). Vyse (1997) stated that superstitious beliefs are inconsistent with rational thoughts as well as cultural or personal values. Block and Kramer (2009) established that superstitions are usually supplicated to ward off bad luck or ferry good luck. Scholars affirmed that superstition have profound effect on students' lives, despite being an incredulous belief that is not founded on reason, observation, knowledge and adventure. Rationale for superstitious thinking has gained momentum in the information age consequent on scholars' discovery that decisions even relating to the degree which people rely on superstition belief in their decision to buy goods and services is linked to the risk, uncertainties, and extent of stress. Consequent on evidences from literature on how people rely on superstition thinking and rituals to bring them luck or avert bad luck, this study aims to evaluate the influence of superstitious thinking on students' civic attitudes in urban learning ecologies. 


\section{Civic Attitudes}

Civic attitudes are individual's dispositions to issues of popular concerns. Barber, Torney-Purta, Wilkenfeld, and Ross (2015) remarked that civic attitudes are part of the emergent participatory citizenship multidimensional construct that enables young people to retain full citizenship maturity. These scholars reiterated that the writings on emergent participatory citizenship placed appreciable prominence on civic attitudes. It should be noted that civic attitudes differs from civic engagement, while the former focuses on individuals, the latter deals with collective behaviours. In this study, civic attitudes connote a student's positive or negative disposition to issues of public concerns.

\section{Urban Learning Ecologies}

Learning ecologies are spaces in which learning occur (Siemens 2007; Ige and Hlalele 2017). Jackson (2013) affirmed that the ecological metaphor has been found appropriate for several contexts and appropriately suited to human interactions. O'Toole (2011) highlighted the features of ecology in the traditional perspectives as:

- a habitat in which individuals of numerous species co-live in relative stability and inter-dependence.

- a self-regulating system that consumes and reuse resource

- a set of over-lapping but well defined territories and niches with peculiar rules, affordances and checks.

- a dynamic organisation modifying people, species andantes-relations without dismantling the connections and balance.

Jackson (2013) complemented these and concluded that an individual's learning ecology comprises their process and set of contexts as well as interactions that provides them with opportunities and resources for learning, development, and attainment. This scholar further stated that learning ecologies are a feature of both formal and informal learning settings. The formal learning ecologies are determined by teachers, and institutions, while informal learning ecologies are determined by individuals and groups. In this study, urban learning ecologies are spaces (schools) in which learning occurs in urban geographical locations.

\section{METHOD}

\section{Design}

The descriptive survey of field-based type which utilized a structured questionnaire was used for data collection. This design was used because the variables that the researcher investigated in this study have manifested, and were only studied in the milieu in which they have manifested.

\section{Sample}

167 secondary school students were purposefully selected in eight secondary schools across different urban geographical locations in Nigeria. These students were purposefully selected because they were willing to participate in the study, and their 
schools offered civic education. The 167 selected secondary school students were 88 $(47.3 \%)$ female and $79(52.7 \%)$ male.

\section{Instruments}

The instruments used for data collection were the 'Senior Student Thinking Dispositions Questionnaire (SSTDQ)', and 'Students' Attitudes to Civic Education Scale (SACES)', adapted from Kokis, Macpherson, Toplak, West, and Stanovich (2000), and Ige (2013).

The 'PTDQ' is a questionnaire that comprises fifty-three statements with eight subscales. The selected school prefects responded to each statement on a six-point scale of 6 (strongly agree), 5 (moderately agree), 4 (slightly agree), 3 (slightly disagree), 2 (moderately agree), and 1 (strongly agree). In our quest to gain utmost insights into school prefects thinking disposition variables and achievement, and to improve the psychometric properties of the instruments, the components of the thinking disposition questionnaire were grouped into compartments (see Mizala, Martinez, \& Martinez, 2015; Del Rio \& Balladares, 2010). The 'Prefects Thinking Dispositions Questionnaire' has eight sub-scales, and was subjected to Cronbach alpha for reliability coefficient. The reliability coefficients are as follow: flexible thinking sub-scale $(\alpha=0.64)$, openness values $(\alpha=0.62)$, Dogmatism $(\alpha=0.62)$, categorical thinking $(\alpha=0.67)$, beliefs identification $(\alpha=0.69)$, counterfactual thinking $(\alpha=0.70)$, absolutism $(\alpha=0.66$, and superstitious thinking $(\alpha=0.75)$. The overall reliability of the 'PTDQ' employing Cronbach Alpha was 0.72 .

Section B contains 22 graduated questions which comprise modified likert 4-point scale of Strongly Agree (SA), Agree (A), Disagree (D) and Strongly Agree (SA). The scale was designed to measure the achievement of basic civic attitudes for identifying civic problems and issues in the learners' immediate environment, inculcation of the right values and skills that will enable students to actively participate in the civic process, and the development of a sense of moral responsibility to citizenship education.

The statements were scored by allotting 4 points to SA, 3 to A, 2 to D and 1 to SD for positively worded statements, which was reversed for negatively worded statements. The reliability of the questionnaire using Cronbach Alpha method was 0.76

\section{Procedure of Data Collection}

Meetings were initiated with the management of the selected schools. The researcher gave adequate briefing to the officials on the study, and sought informed consent from the students of the eight selected secondary schools that participated in this study, with initial discussion on the purpose of the study discussed with members of management teams of the selected schools in urban geographical locations. Data was collected from the selected schools for a period of six weeks.

\section{Data Analysis}

The data was subjected to multiple linear regression analysis using Statistical Package for Social Sciences (24.0). The attitude scores of the participants in civic education were transformed to z-scores, and used for analysis. Scatter plots were plotted to ascertain the 
existence of linear relationship between the dependent and independent variables in the model of multiple linear regression. The variables were not forced into the regression model to confirm the variables that are capable to provide information on additional variance in the model.

\section{FINDINGS}

Answering the Research Questions

Which of the critical thinking disposition sub-constructs will be the potent predictors of students' civic attitudes?

Table 1

Potent Predictors of Students' Civic Attitudes

\begin{tabular}{|c|c|c|}
\hline Variables & Variables Removed & Method \\
\hline Absolutism & $\begin{array}{l}\text { Gender, Age, Flexible_Thinking, } \\
\text { Openness_Value, Dogmatism, } \\
\text { Categorical_Thinking, Beliefs_Identification, } \\
\text { Counterfactual, Superstitious Thinking, } \\
\text { School Location }\end{array}$ & $\begin{array}{l}\text { Stepwise (Criteria: Probability- } \\
\text { of-F-to-enter }<=.050, \\
\text { Probability-of-F-to-remove }>= \\
.100) .\end{array}$ \\
\hline $\begin{array}{l}\text { Superstitious } \\
\text { Thinking }\end{array}$ & $\begin{array}{l}\text { Gender, Age, Flexible Thinking, Openness } \\
\text { Value, Dogmatism, Categorical Thinking, } \\
\text { Beliefs Identification, Counterfactual, } \\
\text { School Location }\end{array}$ & $\begin{array}{l}\text { Stepwise (Criteria: Probability- } \\
\text { of-F-to-enter }<=.050, \\
\text { Probability-of-F-to-remove }>= \\
.100) \text {. }\end{array}$ \\
\hline Dogmatism & $\begin{array}{l}\text { Gender, Age, Flexible Thinking, Openness } \\
\text { Value, Categorical Thinking, Beliefs } \\
\text { Identification, Counterfactual, School } \\
\text { Location }\end{array}$ & $\begin{array}{l}\text { Stepwise (Criteria: Probability- } \\
\text { of-F-to-enter }<=.050, \\
\text { Probability-of-F-to-remove }>= \\
.100) \text {. }\end{array}$ \\
\hline
\end{tabular}

Table 1 show that absolutism, superstitious thinking, and dogmatism are the most potent predictors of students' civic attitudes from gender, school location, age and thinking disposition sub-constructs entered into our stepwise linear regression model.

Research Question Two: What are the combined contributions of the potent critical thinking disposition sub-constructs to the criterion of students' civic attitudes?

Table 2

Contributions of the potent critical thinking disposition sub-constructs to the criterion of students' civic attitudes

\begin{tabular}{llllll}
\hline Model & $\mathrm{R}$ & R Square & $\begin{array}{l}\text { Adjusted } \\
\text { R Square }\end{array}$ & $\begin{array}{l}\text { Std. Error of the } \\
\text { Estimate }\end{array}$ & $\begin{array}{l}\text { Durbin- } \\
\text { Watson }\end{array}$ \\
\hline 1 & $.353^{\mathrm{a}}$ & .125 & .119 & .93845839 & \\
\hline 2 & $.422^{\mathrm{b}}$ & .178 & .168 & .91229584 & \\
\hline 3 & $.449^{\mathrm{c}}$ & .202 & .187 & .90172229 & 1.905 \\
\hline
\end{tabular}
a. Predictors: (Constant), Absolutism
b. Predictors: (Constant), Absolutism, Superstitious_Thinking
c. Predictors: (Constant), Absolutism, Superstitious_Thinking, Dogmatism
d. Dependent Variable: Zscore(Civic_Attitudes) 
Table 3

Contributions of the potent critical thinking disposition sub-constructs to the criterion of students' civic attitudes

\begin{tabular}{|c|c|c|c|c|c|c|}
\hline \multicolumn{2}{|c|}{ Model } & Sum of Squares & $\mathrm{df}$ & Mean Square & $\mathrm{F}$ & Sig. \\
\hline \multirow[t]{3}{*}{1} & Regression & 20.684 & 1 & 20.684 & & 23.486 \\
\hline & Residual & 145.316 & 165 & $.000^{\mathrm{b}}$ & & \\
\hline & Total & 166.000 & 166 & .881 & & \\
\hline \multirow[t]{3}{*}{2} & Regression & 29.505 & 2 & 14.753 & & 17.726 \\
\hline & Residual & 136.495 & 164 & $.000^{\mathrm{c}}$ & & \\
\hline & Total & 166.000 & 166 & .832 & & \\
\hline \multirow[t]{3}{*}{3} & Regression & 33.464 & 3 & 11.155 & & 13.719 \\
\hline & Residual & 132.536 & 163 & $.000^{\mathrm{d}}$ & & \\
\hline & Total & 166.000 & 166 & .813 & & \\
\hline
\end{tabular}

a. Dependent Variable: Zscore(Civic_Attitudes

b. Predictors: (Constant), Absolutism

c. Predictors: (Constant), Absolutism, Superstitious_Thinking

d. Predictors: (Constant), Absolutism, Superstitious_Thinking, Dogmatism

A hierarchical regression analysis was conducted in which the independent variables were regressed on the civic attitudes of the selected secondary school students. Absolutism turns to be the strongest predictor of students' civic attitudes accounting for $12.5 \%$ of the total variance $\left(\Delta \mathrm{R}^{2}=.125,\left(\Delta \mathrm{F}_{(1,165)}=23.49, \mathrm{p}<0.05\right)\right.$. This result confirms that absolutism is the most potent predictor of students' civic attitudes. The results further revealed that superstitious thinking when added to absolutism altered the prediction to $17.8 \%$ of the total variance $\left(\Delta \mathrm{R}^{2}=.178,\left(\Delta \mathrm{F}_{(2,164)}=17.73, \mathrm{p}<0.05\right)\right.$. It was shown from the output of the stepwise linear regression model on the SPSS that the prediction surged to $20.2 \%$ of the variance when dogmatism got added to the initial two potent predictors $\left(\Delta \mathrm{R}^{2}=.202,\left(\Delta \mathrm{F}_{(3,163)}=13.72, \mathrm{p}<0.05\right)\right.$. It should be noted that the stepwise hierarchical regression analysis excluded other variables entered into the model as not significant in the prediction of civic attitudes of the participants. The DurbinWatson (d) value of 1.905 affirms that there is no first order linear auto-correlation in the data of the multiple linear regression, since it falls between the critical values of $1.5<\mathrm{d}<2.5$.

Research Question Three: What are the relative contributions of the potent critical thinking disposition sub-constructs to the criterion of students' civic attitudes? 
Table 4

Respective contributions of the potent critical thinking disposition sub-constructs to the criterion of students' civic attitudes

\begin{tabular}{|c|c|c|c|c|c|c|c|}
\hline \multirow[t]{2}{*}{ Model } & \multicolumn{2}{|c|}{$\begin{array}{l}\text { Unstandardized } \\
\text { Coefficients }\end{array}$} & \multirow{2}{*}{$\begin{array}{l}\text { Standardized } \\
\text { Coefficients } \\
\text { Beta } \\
\end{array}$} & $\mathrm{t}$ & \multirow[t]{2}{*}{ Sig. } & \multicolumn{2}{|c|}{$\begin{array}{l}\text { Collinearity Statistics } \\
\text { Tolerance }\end{array}$} \\
\hline & B & Std. Error & & VIF & & & \\
\hline 1 (Constant) & -1.753 & .369 & & -4.751 & .000 & & \\
\hline Absolutism & .072 & .015 & .353 & 4.846 & .000 & 1.000 & 1.000 \\
\hline 2 (Constant) & -2.253 & .390 & & -5.774 & .000 & & \\
\hline Absolutism & .064 & .015 & .317 & 4.429 & .000 & .977 & 1.024 \\
\hline Superstitious & .028 & .009 & .233 & 3.256 & .000 & .977 & 1.024 \\
\hline Thinking & & & & & & & \\
\hline $\begin{array}{ll}3 & (\text { Constant })\end{array}$ & -2.953 & .390 & & -5.774 & .000 & & \\
\hline Absolutism & .053 & .015 & .262 & 3.497 & .001 & .869 & 1.150 \\
\hline Superstitious & .025 & .009 & .210 & 2.940 & .004 & .956 & 1.046 \\
\hline Thinking & & & & & & & \\
\hline Dogmatism & .024 & .011 & .167 & 2.207 & .029 & .859 & 1.164 \\
\hline
\end{tabular}

a. Dependent Variable: Zscore (Civic_Attitudes)

Table 3 shows that absolutism is the most relative predictor of secondary school students' civic attitudes $(\mathrm{B}=.353, \mathrm{t}=4.846, \mathrm{p}<0.05)$. It was followed by superstitious thinking $(\mathrm{B}=.233, \mathrm{t}=3.256, \mathrm{p}<0.05)$, and dogmatism $(\mathrm{B}=.167, \mathrm{t}=2.207, \mathrm{p}<0.05)$. The tolerance statistic and the Variance Inflation Factor were used to evaluate the absence of multi-collinearity amidst the independent variables. Table 3 shows the nonexistence of multi-collinearity among the independent variables as the tolerance and VIF values were normal.

\section{DISCUSSION}

A rigorous research through academic resources on different online database shows that this study is the first that would evaluate the influence of critical thinking dispositions on students' civic attitudes in urban schools. Previously, Selhaug (2006) researched into the influence of knowledge and self-efficacy on popular participation and civic attitudes focusing on the relevance for educational practice. Selhaug (2006) discovered that knowledge is a stronger predictor of civic attitudes than self-efficacy. This study was among the earliest few that confirmed that competence other than knowledge is integral to civic participation. Recently, Costa (2013) wrote a philosophical treatise on civic virtues of students in character schools highlighting the potentials of schools as seedbeds of civic virtues, and unveiled the approach that effective schools are using to foster civic virtues. Costa (2013) concluded by questioning schools techniques of cultivating broad dispositions underlying good citizenship in charter schools. The pioneering effort of this study is confronted by the limitations of situating the current findings with previous discourses at local and global levels.

Despite the limitation, the researcher tried to make a well thought out relation to prior studies considering the result of the first research question, it is discovered that absolutism, superstitious thinking, and dogmatism are the most potent critical thinking dispositions frames that predicted students' civic attitudes. This finding attested to 
Giancarlo, Blohm, and Urdan (2004) assertion that critical thinking dispositions are essential constructs that is powerful and vital in students' academic and personal engagements.

The second question in this study scrutinized the combined contribution of the potent critical thinking dispositions on the criterion of students' civic attitudes. The findings revealed that absolutism, superstitious thinking and dogmatism contributed significantly to civic attitudes of students in urban learning ecologies. These critical dispositions constructs effectively combined to influence students' civic attitudes. The implications of the findings are that these three thinking constructs are at work in students displaying functional citizenship ideals. This finding confirms the outcomes of Dayal and Kaur (2015) that superstitious attitude has a significant influence on the mental health of rural and urban female teachers, as well as Nguyen and Rowatt (2012) whose study supported that pro-superstitious priming can potentially influence inclination towards superstitious attitudes and behaviors.

The third research question investigated the independent determinacy (Aremu 2004; Ige 2015) of the effective critical thinking disposition constructs on students' civic attitudes. Evidences from this study shows that the three potent thinking constructs had significant relative contributions in varied fragments. Absolutism had the highest contributing value of $\mathrm{t}=4.8486$ to the civic attitudes of the students, which is followed by superstitious thinking ( $\mathrm{t}=3.256)$, and dogmatism $(\mathrm{t}=2.207)$. While the results are not supported by any prior study on civic attitudes of secondary school students. A related study conducted by Ige (2016) confirmed that absolutism, superstitious attitude, and dogmatism have relative influence on students' academic self-concept. In the study conducted Ige (2016) dogmatism had the most relative influence $(t=7.789)$, superstitions had a t-value of 2.508 , while absolutism had the lowest relative influence $(t=-8.394)$. These results empirically attested to the research outcomes of scholars that critical thinking dispositions have profound impacts on students' learning outcomes (Mok \& Yuen, 2016; Bloch \& Spataro, 2014; Franco, Costa, Butler, \& Almeida, 2017; Ige, 2016).

\section{CONCLUSION}

This study has implications for teaching and learning of civic education in secondary schools, consequent on the mission of schools in producing students with competent citizenship qualities. It has been unveiled in the study that the civic attitude of secondary schools is influenced by their critical thinking dispositions. Consequent on the findings of this discourse, it is proposed that teachers should teach critical thinking disposition constructs to empower students for functional civic participation in Nigeria. Specifically, teachers should use teaching strategies that are non-gender centered to develop absolutism, superstitious thinking, and dogmatism frames in students. This would enable students to transfer the knowledge imparted by teachers in school settings to subtle civic issues in the larger society, and their immediate environments. Curriculum developers should also infuse critical thinking dispositions into the curricula of civic education at different levels of schooling in Nigeria. As good as the recommendations are, caution should be made to generalize the findings to other parts 
of Nigeria because the participants in the study were selected from eight secondary schools in the northern and south-west, Nigeria. These limitations notwithstanding, this study is philosophically relevant to the field of teacher education.

\section{REFERENCES}

Aremu, A. O. (2004). A confluences of credentialing career experience, self-efficacy, emotional intelligence, and motivation on their career commitment of young police in Ibadan, Nigeria. Policing: An International Journal of police Strategies \& Management, 28(4), 609-618.

Barber, C., Torney- Purta, J., Wilkenfeld, B., \& Ross, J. (2015). Immigrant and nativeborn adolescents' civic knowledge and attitudes in Sweden and the United States: Emergent citizenship within developmental niches. Research in Comparative \& International Education, 10(1), 23-47.

Barren, J. (1993). Why teach thinking? An essay. Applied Psychology: An International Review, 42, 191-214.

Bloch, J., \& Spataro, S. E. (2014). Cultivating critical-thinking dispositions throughout the business curriculum. Business and Professional Communication Quarterly, 77(3), 249-265.

Block, D. (1994). Scientific basis for beliefs. An extract from a lecture delivered in the University of Johannesburg. South Africa Star of 3/6/1994.

Block, L., \& Kramer, T. (2009). The effect of superstitious beliefs on performance expectations. Journal of the Academy Marketing Science, 37(2), 161-169.

Brock, F. J., Paddock, C. E., \& Thomson, W. E. (1993). Effects of dogmatism on computer literacy. Journal of international information Management, 2(2), 28-147.

Brock, F. J., Paddock, C. E., \& Thomsen, W. E. (1993). Effects of dogmatism on computer literacy. Journal of International Information Management, 2(2), 28-48.

Burkhalter, N., \& Shegabayev, M. (2010). The critical thinking movement in Kazakhstan: A progress report. Research in Comparative and International Education, 5(4), 434-445.

Campbell, D. E. (2007). Sticking together: Classroom diversity and civic education. American Politics Research, 35(1), 57-78.

Costa, M. V. (2013). Civic virtue and high commitment schools. Theory and Research in education 11(2), 129-134.

Dayal, J. K., \& Kaur, M. (2015). Impact of superstitious attitude on mental health of women teachers. Indian Journal of Research, 4(7), 79-81.

Dayar, K. J., \& Kaur, M. (2015). Impact of superstitious attitude on mental health of women. Indian Journal of Research (PARIPEX), 4(7), 79-81. 
Doyle, K. A. (2014). The dangers of dogmatism. Retrieved 24 April 2017 from http:llwww.albertellis.org/the-dangers-of-dogmatism

Ennis, R. H. (1987). A taxonomy of critical thinking dispositions and abilities. In Baron, J. B. \& Sternberg, R. J. (Ed), Teaching thinking skills: Theory and practice (pp. 9-26). New York: W.H. Freeman \& Company.

Facione, P. A. (2013). Critical thinking: What it is and why it counts. Insight assessment, ISBN 13:978-1-891-557-07-1. Retrieved 12 April 2017 from https://www.nyack.edu/files/CT_What_Why_2013.pdf

Facione, P. (1990). Critical thinking: A statement of expert consensus for purposes of educational assessment and instruction (The Delphi Report).

Fairbrother, P. G. (2003). The effects of political education and critical thinking on Hong Kong and mainland Chinese university students' national attitudes. British Journal of Sociology of Education, 24(5), 605-620.

Fero, L. J., O’Donnell, J. M., Zullo, T. G., Dabbs, A. D., Kitutu, J., Samosky, J. T., \& Hoffman, L. A. (2010). Critical thinking skills in nursing students: Comparison of simulation-based performance with metrics. Journal of Advanced Nursing, 66(10), 2182-2193.

Franco, A. R., Costa, P. S., Butter, H. A., \& Almeida, L.S. (2017). Assessment of undergraduates' real-world outcomes of critical thinking in everyday situations. Psychological Reports, 1-14.

George, S., \& Sreedhar, P. K. (2006). Globalisation and the prevalence of superstitious beliefs. Journal of the Indian Academy of Applied Psychology, 32(3), 241-247.

Giancarlo, C. A., Blohm, S. W., \& Urban, T. (2004). Assessing secondary students' disposition toward critical thinking: Development of the California measure of mental motivation. Educational and Psychological Measurement, 64(2), 347-364.

Hare, W. (2004). Open-minded inquiry: A glossary of key concepts. Inquiry: Critical Thinking Across Disciplines, 23(3), 37-41.

Hatemi, P.K., \& Verhulst, B. (2015). Political attitudes develop independently of personality traits. Plos One, 10(7), 1-24.

Hess, D. (2004). Controversies about controversial issues in democratic education. PSOnline, April, pp.257- 261.

Ige, O. A. (2016). Thinking dispositions factors influencing secondary school students' academic self concept and concept and achievement in civic education in Ondo and Osun states, Nigeria. Australia and New Zealand Journal of Social Business, Environment and Sustainability, 2(1), 1-14.

Ige, O. A. (2015). Computer self-efficacy, computer competency, commitment to ethical goodness and community bonding factors influencing pre service teachers' internet self efficacy in SouthWest, Nigeria. Carribean Educational Research Journal. 3(1), 44-61. 
Ige, O. A. \& Hlalele, D. J. (2017). Effects of computer-aided and blended teaching strategies on students' achievement in civic education concepts in mountain learning ecologies. Education and Information Technologies. DOI 10.1007/s10639-017-9598-x.

Jackson, J. N. (2013). The concept of learning ecologies. Retrieved 10 May 2017 from http:llwww.lifewidebook.co.uk/uploads/1/0/8/4/1.pdf

Klooster, D. (2001). What is critical thinking? The thinking classroom, 1, 36-40.

Kökdemir, D. (2003). Belirsizlik durumlarinda karar verme ve problem çözme (Unpublished doctoral thesis). Ankara University, Ankara.

Kuhn, D., Cheney, R., \& Weinstock, M. (2000). The development of epistemological understanding. Cognitive Development, 15, 309-328.

McDonald, J. (1992). An examination of the influence of school mediated variables on academic achievement (Unpublished doctoral dissertation). Dublin City University, United Kingdom.

McDonald, J. (1992). An examination of the influence of school mediated variables on academic achievement. Master of thesis, Dublin City University.

Mok, F. K. T., \& Yuen, T. W. W. (2016). A critical evaluation of the understanding of critical thinking by school teachers: the case of Hong Kong. Citizenship, Social and Economics Education, 15(1), 28-44

Nakagawa, Y. (2016). Effect of critical thinking disposition on household earthquake preparedness. Natural Hazards, 81(2), 807-828.

O'Toole, R. (2011). What is a learning ecology? Retrieved 10 May 2017 from https:llwww2.warwick.ac.uk/fac/cross/

Ogundokun, M. O., \& Adeyemo, D. A. (2010). Emotional intelligence and academic achievement: The moderating influence of age, intrinsic, and extrinsic motivation. The African Symposium: An online Journal of the African Educational Research Network, 10(2), 127-141.

Oguz, A., \& Saricam, H. (2016). The relationship between critical thinking and locus of control in pre-service teachers. Journal of Education and Training Studies, 4(2), 182192.

Rex, C. M. (2012). Strategic and critical thinking. Retrieved 13 April 2017 from http:www.csun.edu/-hfongt001ist-cr-thinking.doc

Ribeiro, A. E., \& Borba, J. (2016). Personality, political attitudes and participation in protests: The direct and mediated effects of psychological factors on political activism. Brazilian Political Science Review, 10(3), 1-33.

Rickles, M. L., Schneider, R. Z., Slusser, S. R., Williams, D. M., \& Zipp, J. F. (2013). Assessing change in critical thinking for introduction to sociology classes. Teaching Sociology, 4l(3), 271-281. 
Roberts, B. W., Robins, R. W., Trzesniewski, K., \& Caspi, A. (2003). Personality trait development in adulthood. In Mortimer J, Shanahan M, (Ed), eHandbook of the life course. New York: Kluwer Acad.

Siemens, G. (2007). Connectivism: Creating a learning ecology in disturbed environments. In T. Hug (Ed), Didactics of microlearning: concepts, discourses, and examples munster: Waxman.

Solhaug, T. (2006). Knowledge and self-efficacy as predictions of political participation and civic attitudes. Policy Futures in Education, 4(3) 265-278.

Stanovich, K.E., \& West, R. F. (1997). Reasoning independently of prior belief and individual differences in actively open-minded thinking. Journal of Educational Psychology, 89, 342-357.

Tobin, K. (2010). Civic education in emerging democracies: Lessons from postCommunist Poland and Romania. Journal of Research in International Education, 9(3), 273-288.

Undie, J. U., Duruamaku, D. J., Agba, R. U., \& Undie, U. U. (2015). Superstitious beliefs and academic Performance of pupils in early childhood science in Ogojo educational zone, South Eastern, Nigeria. British Journal of Education, 3(11), 54-62.

Villegas, M. A. (2007). Dispositions in teacher education: A look at social justice. Journal of Teacher Education, 58(5), 370-380.

Vyse, S. A. (1997). Believing in magic: The psychology of superstition. New York: Oxford University Press.

Westheimer, J., \& Kahne, J. (2004). What kind of citizen? The politics of education for democracy. American Educational Research Journal, 41(2), 237-269

Yuen, T. W. W. (2016). Civic education stuck in quagmire: A critical review of civic education in Hong Kong? Citizenship, social and economics education, 15(2), 69-82. 
APPENDIX I

\section{Histogram}

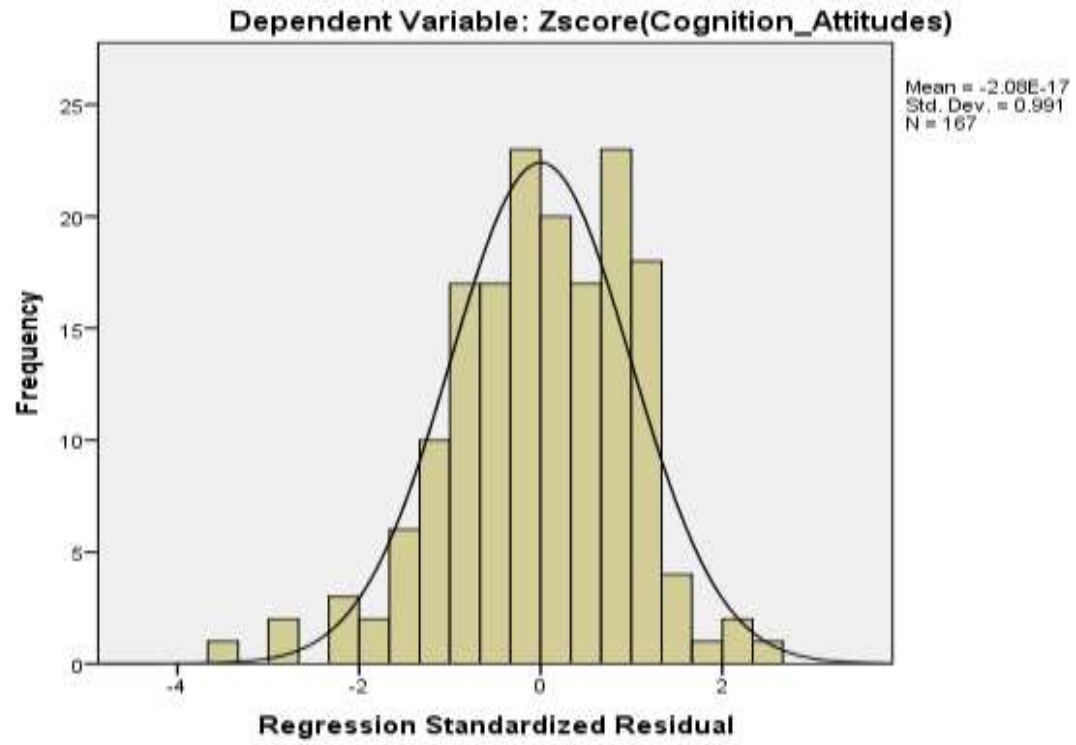

Appendix II

Normal P-P Plot of Regression Standardized Residual

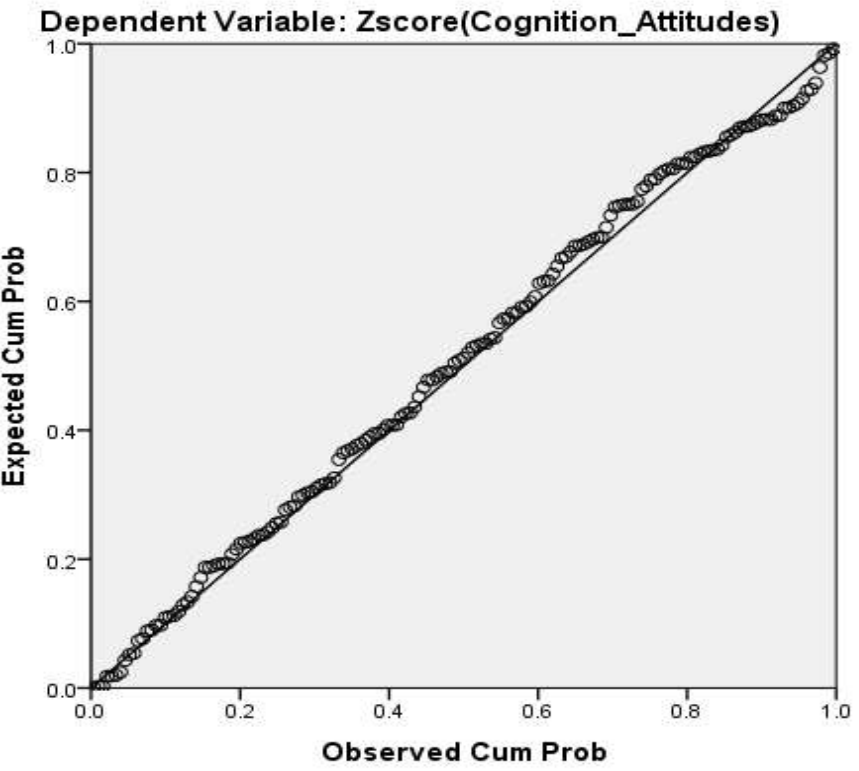

International Journal of Instruction, October $2017 \bullet$ Vol.10, No.4 
Appendix III

\section{Scatterplot}

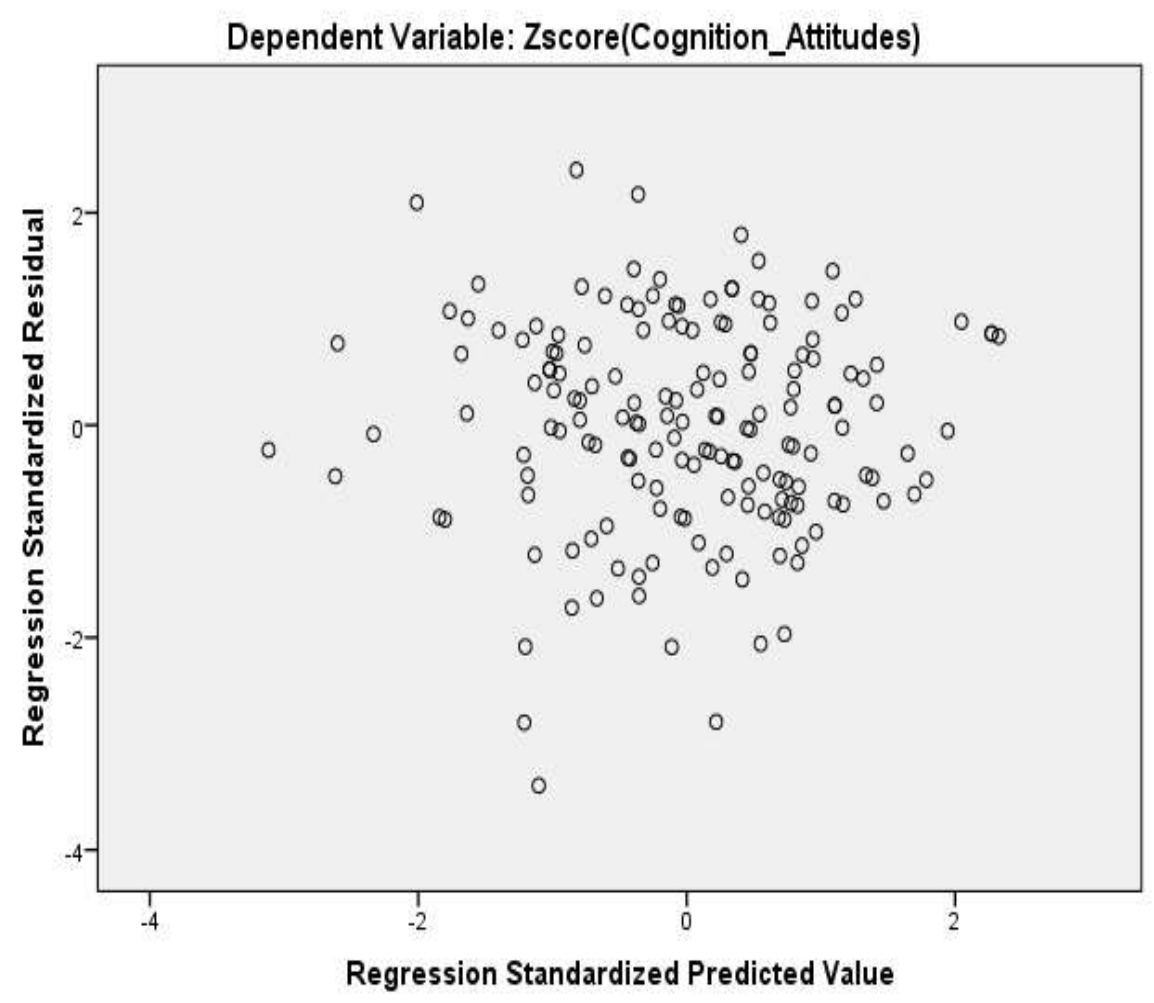

International Journal of Instruction, October $2017 \bullet$ Vol.10, No.4 
Turkish Abstract

\section{Kentsel Öğrenme Ortamlarında Öğrencilerin Sivil Görev Yönündeki Yönergelerini Yeniden Düşünmek}

$\mathrm{Bu}$ çalışma, orta öğretim öğrencilerinin okul ekolojilerindeki düşünce tutumlarının etnik topluluk tutumlarına etkisini araştırmıştır. Kuzey ve Güney Nijerya'daki seçilen sekiz ortaokuldan 167 öğrenciye, Kıdemli Öğrencilerin Düşünce Dağılımları Anketi (SSTDQ) ve Öğrencilerin Sivil Eğitime Tutum Ölçeği (SACES) uygulanmıştır. Adım adım doğrusal regresyon modelinin sonuçları, mutlakiyetçilik, batıl inanç ve dogmatizmanın, öğrencilerin yurttaş tutumlarına güçlü bir şekilde bağlı güçlü yordayıcılar olduğunu göstermiştir.

Anahtar Kelimeler: eleştirel söylem, sivil tutumlar, kentsel öğrenme ortamı, batıl inanç, dogmatizm

\section{French Abstract}

Reconception des Dispositions d'Étudiants vers Devoirs(Droits) Civiques dans Écologies d'Apprentissage Urbaines

Cette étude a exploré l'influence causative de dispositions pensantes sur les étudiants de collège d'enseignement général des attitudes civiques dans des écologies scolaires. 167 étudiants de huit collèges d'enseignement général choisis au Nigeria du nord et du sud ont répondu au Questionnaire de Dispositions de Pensée des Étudiants Seniors (SSTDQ) et l'Attitude des Étudiants à l'Échelle d'Enseignement(Éducation) Civique (des SACS). Les résultats du modèle de régression linéaire point par point ont déclaré que l'absolutisme, la superstition et le dogmatisme étaient les prophètes puissants qui sont fortement connectés aux attitudes civiques des étudiants. L'étude a des inférences pour le développement des professeurs viz un viz les attitudes civiques des étudiants enseignants de l'intérieur de dans des écologies scolaires.

Mots Clés: discours critique, attitudes civiques, écologies d'apprentissage urbaines, absolutisme, pensée superstitieuse, dogmatisme

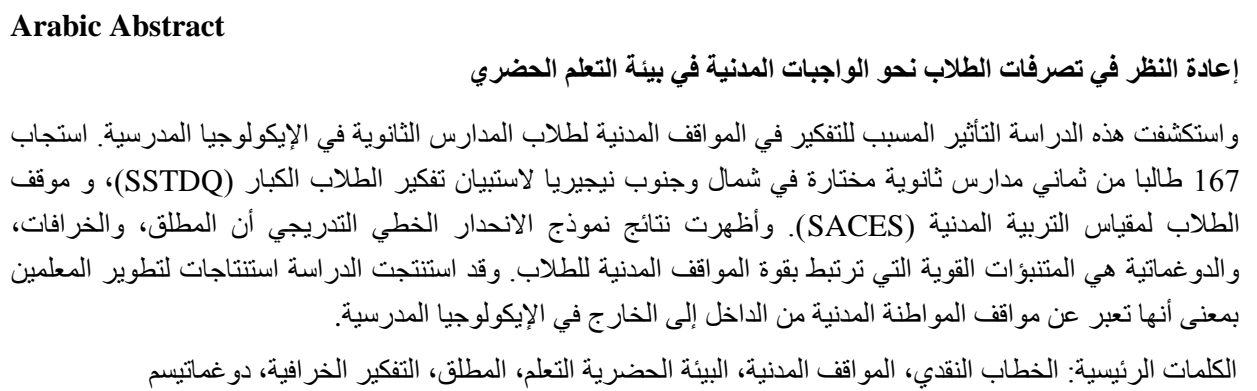




\section{German Abstract \\ Die Dispositionen der Studenten in Richtung der bürgerlichen Pflichten in städtischen Lernökologie zu überdenken}

Diese Studie erforschte den ursächlichen Einfluss der Denkverhältnisse auf die Zivilgesellschaft der Schülerinnen und Schüler in Schulökologien. 167 Schüler aus acht ausgewählten Sekundarschulen im Norden und Süden Nigerias reagierten auf den Senioren-Thinking Dispositions-Fragebogen (STDF) und die Einstellung der Schüler zum Civic Education Scale (SCES). Die Ergebnisse des schrittweisen linearen Regressionsmodells erklärten, dass Absolutismus, Aberglaube und Dogmatismus die starken Prädiktoren waren, die stark mit den bürgerlichen Einstellungen der Studenten verbunden sind. Die Studie hat Schlussfolgerungen für die Lehrer-Entwicklung viz ein viz Lehre Studenten bürgerlichen Einstellungen von innen in der Schule Ökologie.

Schlüsselwörter: kritischer diskurs, bürgerliche einstellungen, städtische lernökologie, absolutismus, abergläubisches denken, dogmatismus

\section{Malaysian Abstract \\ Memikirkan semula Peluang Pelajar terhadap Kewajipan Sivik dalam Ekologi Pembelajaran Bandar}

Kajian ini meneroka pengaruh kaitan pemikiran terhadap sikap sivik pelajar sekolah menengah dalam ekologi sekolah. 167 pelajar dari lapan sekolah menengah terpilih di utara dan selatan Nigeria bertindak balas kepada Questionnaire Dispositions Thinking Students (SSTDQ), dan Sikap Pelajar untuk Skor Pendidikan Sivik (SACES). Hasil model regresi linear stepwise mengisytiharkan bahawa absolutisme, superstition, dan dogmatisme adalah peramal yang kuat yang sangat berkaitan dengan sikap sivik pelajar. Kajian ini mempunyai kesimpulan untuk pembangunan guru yang mengajar sikap sivik pelajar dari luar dalam ekologi sekolah.

Kata Kunci: wacana kritis, sikap sivik, ekologi pembelajaran bandar, absolutisme, superstition, dogmatisme

\section{Russian Abstract \\ Переосмысление Студенческих Диспозиций по Гражданским Обязанностям в Экологическом Образовании в Городах \\ В этом исследовании изучалось причинное влияние умственных способностей на гражданское отношение школьников к школьным экологиям. 167 студентов из восьми отобранных средних школ в северной и южной Нигерии ответили на вопросник мыслительных диспозиций студентов старших курсов (SSTDQ) и отношение учащихся к шкале гражданского образования (SACES). Результаты ступенчатой линейной регрессионной модели заявили, что абсолютизм, суеверие и догматизм являются мощными предикторами, которые сильно связаны с гражданскими отношенияи учащихся. В исследовании приводятся выводы для развития учителей, а именно: преподавание студенческих гражданских взглядов извне в школьных экологиях.}

Ключевые Слова: критический дискурс, гражданское отношение, экология городского обучения, абсолютизм, суеверное мышление, догматизм 